\title{
Social Networks as a Tool for Leadership in Entrepreneurship Ecosystem
}

\author{
Viktoria Simonova \\ Institute of Economics, Ural Branch of the Russian Academy of Sciences \\ Moskovskaya str. 29, 620014 Ekaterinburg \\ Ural Federal University \\ Mira str. 19, 620002 Yekaterinburg \\ Russian Federation \\ e-mail: vlsimonova1409@gmail.com \\ Evgeny Popov \\ Institute of Economics, Ural Branch of the Russian Academy of Sciences \\ Moskovskaya str. 29, 620014 Ekaterinburg \\ Ural Federal University \\ Mira str. 19, 620002 Yekaterinburg \\ Russian Federation \\ e-mail: epopov@mail.ru \\ Oxana Komarova \\ Institute of Economics, Ural Branch of the Russian Academy of Sciences \\ Moskovskaya str. 29, 620014 Yekaterinburg \\ Ural Federal University \\ Mira str. 19, 620002 Yekaterinburg \\ Russian Federation \\ e-mail: okkomarova@yandex.ru
}

\begin{abstract}
In the spread of digital technologies, the development of entrepreneurship ecosystems based on social networks is considered to be a business development strategy contributing to the achievement of market leadership. The value of entrepreneurship ecosystems development is determined by the effects of using social networks.

Our paper shows that the effects of using social networks may occur at different levels and may also be both positive and negative. At the microeconomic level using social media expands markets for products though causing an increase in competition among companies. Networking at the meso-economic level is a positive effect; however, there is a shift in industry proportions in the economy towards the services sector. And, finally, at the macroeconomic level using social media encourages the development of the domestic market, but this is accompanied by an increase in costs of control and maintenance of economic institutions. In addition, the strategy for the development of entrepreneurship ecosystems is to consider a regional and content differentiation of social networks.

Furthermore, our paper analyzes a regional differentiation of social networks markets considering certain global and national features of their development. The analysis of a content differentiation included studying the development of field- specific sites of social networks.
\end{abstract}

\section{Introduction}

Economists consider enterprise ecosystem formation as the development of a strategy and environment for business development contributing to the achievement of market leadership. Economic ecosystem represents a unity of the interlinked and interactive economic subjects, each of which benefits not only through its own functioning but also through functioning of other economic agents (Martins 2016; Obst et al. 2016). Ecosystems development promotes new ways and rules of interacting of all participants of production, allocation, exchange and consumption of economic benefits; provokes emergence of new economic benefits.

Social networks enable entrepreneurs to gain access to large amounts of information, stimulate the emergence of new tools for selling, marketing and development of the communities (Wu et al. 2013; Hornuf and Schwienbacher 2018). Social networks, therefore, encourage the development of new entrepreneurship ecosystems, while social networks applications and platforms are widely spread, with an unprecedented number of users, consumers, voters, enterprises, governments and not-for-profit organizations (Zeng et al. 2010; Abrhám 
and Wang 2017). Entrepreneurship ecosystems development is based on key features of social networks communication: trusting relationship, personification, wide and fast distribution of information. This kind of interaction with a consumer provides a high-quality feedback, which is particularly crucial because it is a consumer's voice that is critical for shaping and adjusting the functioning of any organization and affects its business result.

Thus, the key factor of the formation of entrepreneurship ecosystems based on social networks is the openness of information technology infrastructure operating on the "win-win" principle. The value of this ecosystem is determined by the effects of using social networks as well as their regional and content differentiation. All of the above might be very crucial for establishing and maintaining leadership in the entrepreneurship system (see e.g. Selyanskaya et al. 2018).

\section{Economic effects of social networks}

Quite often the new economy is formed around information networks that have no center. Social networks based on using certain digital technologies, on the one hand, mediate existing contacts and, on the other hand, create a new digital environment for communication, thus generating new communications and interactions. Social networks, therefore, become a major platform for communication (see e.g. Chiabai et al. 2014).

Following the principle of openness, social networks have the potential for expansion through the usage of contacts sharing a common basis. In addition, an important feature of social networks is wide and fast distribution of information, including information with a high level of the feedback. The personification of contacts and interactions must be emphasized as able to cause the formation of a knowledge generation chain and individualize both consumption and production.

Table 1. Economic effects of using social media

\begin{tabular}{|c|c|c|}
\hline Positive effects & Negative effects & Use efficiency \\
\hline \multicolumn{3}{|c|}{ Mini-economic } \\
\hline $\begin{array}{l}\text { Using social media decreases a } \\
\text { company's operating costs, increases } \\
\text { staff involvement in a company's life, } \\
\text { their motivation, development of } \\
\text { social capital; a growth in marketing } \\
\text { and production effectiveness }\end{array}$ & $\begin{array}{l}\text { Requires financial, human and } \\
\text { material resources for the } \\
\text { development within a corporate } \\
\text { network, its maintenance and usage }\end{array}$ & $\begin{array}{l}\text { Availability of a corporate social } \\
\text { network, the level of the gained } \\
\text { social capital }\end{array}$ \\
\hline \multicolumn{3}{|c|}{ Microeconomic } \\
\hline $\begin{array}{l}\text { Using social media expands markets, } \\
\text { including through attracting more } \\
\text { consumers, enhancing potential } \\
\text { counterparties and expanding markets } \\
\text { in terms of free goods and sharing; } \\
\text { forming the knowledge generation } \\
\text { chains }\end{array}$ & $\begin{array}{l}\text { Company's transfer to tighter } \\
\text { interaction with a consumer increases } \\
\text { competition among companies, raises } \\
\text { additional costs of goods promotion }\end{array}$ & $\begin{array}{l}\text { Costs of interaction, emergence } \\
\text { of new goods through interaction } \\
\text { with a consumer }\end{array}$ \\
\hline \multicolumn{3}{|c|}{ Meso-economic } \\
\hline $\begin{array}{l}\text { Developing networks, platforms and } \\
\text { clusters to decrease the costs of } \\
\text { interaction }\end{array}$ & $\begin{array}{l}\text { Shift in industry proportions in the } \\
\text { economy towards the services sector }\end{array}$ & $\begin{array}{l}\text { Availability of clusters, the level } \\
\text { of production interpenetration } \\
\text { (connectivity among } \\
\text { companies), } \\
\text { availability of interaction } \\
\text { platforms }\end{array}$ \\
\hline \multicolumn{3}{|c|}{ Macroeconomic } \\
\hline $\begin{array}{l}\text { Development of the domestic market; } \\
\text { attracting domestic savings } \\
\text { (developing alternative channels for } \\
\text { financing); developing remote } \\
\text { employment; trust in the economy }\end{array}$ & $\begin{array}{l}\text { Shift in industry proportions in the } \\
\text { economy towards the services sector; } \\
\text { a growth in the dependence on } \\
\text { imports; an increase in the costs of } \\
\text { maintenance and control of economic } \\
\text { institutions }\end{array}$ & $\begin{array}{l}\text { Costs of control (financing } \\
\text { security measures, sophistication } \\
\text { of a registration procedure), } \\
\text { the volume of alternative } \\
\text { financing channels }\end{array}$ \\
\hline
\end{tabular}

Source: Own results

Much research describing separate effects of using social media has been done. Thus, Lak and Rezaeenour (2018) emphasize the possibility of gaining a competitive advantage by building a social networks-based integrated collaboration architecture which is based on the clients' knowledge. Lechman (2018) refers to social networks as a phenomenon that encourages the spread of new technologies. The research by Drury (2008) shows 
that social networks stimulate an increase in sales, development of partnerships and creating a unique product matching the needs of the clients.

Polzin et al. (2018) demonstrate how entrepreneurial teams are formed. This approach allows analyzing entrepreneurial interactions, crowdfunding, clusters, small and medium business support. Grilli et al. (2018) consider social networks as a part of social capital. Ooms et al. (2018) show the importance of multiple informal relationships in innovative collaboration. Vermeulen and Pyka (2018) refer to spatial issues of network organization as a source of knowledge generation.

Summing up extensive information, the effects of using social networks can be divided into groups according to the impact directions (positive and negative), as well as to the impact objects (mini-, micro-, meso-, and macroeconomic effects). The obtained results are represented in Table 1 that follows.

Thus, social media are considered as a sophisticated object which is possible to view from three sides. On the one-part, social media perform as new markets where the competition for the end consumer is formed. On the other part, social media are able to represent themselves as goods in case an intranet is formed. And, finally, social media play the role of information networks used for effective data exchange, including economic information, and maintenance of the feedback among all economic actors.

Social media are a global phenomenon and may stimulate changes in national markets, enhancement of competition and international security.

\section{A regional and a content differentiation of social networks}

The history of social network websites dates back to 1997, to the start-up of SixDegrees.com, and has advanced with launching major websites like Facebook, Instagram and others. Thus far, social networks became global. A modern culture of social networks is based on their classification from the following points: information-oriented content, users' prospective actions (for example, collaborations, blogs, micro-blogs, content societies etc), coverage criteria (global, national, and local networks), and target audience (end user-oriented networks, companies-oriented networks).

Analysis of social networks trends was performed on 2013-2018 statistical data of the following websites: wearesocial.com, similarweb.com, datareportal.com, statcounter.com, statista.com and alexa.com. The results are represented in Table 2.

Table 2. Share of networks active users, in \%

\begin{tabular}{|c|c|c|c|c|c|c|c|c|c|c|c|c|}
\hline \multirow{3}{*}{$\begin{array}{l}\text { Social network } \\
\text { Year }\end{array}$} & \multirow{2}{*}{\multicolumn{2}{|c|}{$\begin{array}{l}\text { Totally in } \\
\text { the world }\end{array}$}} & \multicolumn{10}{|c|}{ Country } \\
\hline & & & \multicolumn{2}{|l|}{ USA } & \multicolumn{2}{|c|}{ Europe } & \multicolumn{2}{|c|}{ Japan } & \multicolumn{2}{|c|}{ China } & \multicolumn{2}{|c|}{ Russia } \\
\hline & $\stackrel{m}{\circ}$ & $\stackrel{\infty}{2}$ & $\stackrel{m}{\stackrel{n}{1}}$ & $\stackrel{\infty}{\stackrel{2}{2}}$ & $\stackrel{m}{\circ}$ & $\stackrel{\infty}{\stackrel{2}{\sim}}$ & $\stackrel{m}{\stackrel{n}{2}}$ & $\stackrel{\infty}{\stackrel{1}{1}}$ & $\stackrel{m}{\stackrel{n}{N}}$ & $\stackrel{\infty}{\stackrel{\sim}{2}}$ & $\stackrel{m}{\stackrel{n}{2}}$ & $\stackrel{\infty}{\circ}$ \\
\hline Facebook & 66,4 & 68,6 & 49,0 & 62,5 & 76,6 & 72,3 & 46,1 & 39,8 & 14,1 & 30,0 & 13,5 & 22,4 \\
\hline YouTube & 3,0 & 6,9 & 1,7 & 1,55 & 3,4 & 4,9 & 4,7 & 12,5 & 1,4 & 3,9 & 6,4 & 22,5 \\
\hline Pinterest & 11,0 & 13,0 & 25,2 & 25,2 & 2,5 & 10,4 & 3,5 & 12,1 & 8,9 & 7,7 & 1,9 & 6,8 \\
\hline Instagram & & 2,0 & & 1,5 & & 2,7 & & 4,2 & & 0,5 & & \\
\hline Twitter & 9,7 & 7,2 & 8,5 & 6,7 & 8,8 & 6,1 & 36,9 & 27,4 & 22,1 & 8,2 & 7,5 & 14,9 \\
\hline Tumblr & 2,1 & 0,9 & 2,8 & 1,1 & 1,9 & 1,4 & 4,1 & 2,4 & 12,4 & 1,0 & 3,8 & 2,8 \\
\hline Reddit & 2,5 & 0,5 & 4,5 & 0,8 & 1,8 & 0,7 & 1,7 & 0,7 & 16,2 & 1,6 & & \\
\hline StumbleUpon & 4,2 & 0,2 & 7,8 & 0,3 & 2,6 & 0,2 & & 0,1 & 10,9 & 0,1 & & \\
\hline LinkedIn & & 0,2 & & & 0,2 & 0,4 & & 0,3 & 2,8 & 1,9 & & \\
\hline Google+ & 0,2 & 0,3 & & & 0,3 & 0,2 & & 0,3 & 1,0 & 1,0 & & \\
\hline VKontakte & 0,4 & 0,3 & 1,4 & & 0,9 & 0,9 & & & 0,3 & 0,3 & 52,1 & 23,1 \\
\hline Odnoklassniki & & & & & & & & & & & 12,4 & \\
\hline Youku & & 0,02 & 0,3 & & & & & & & 38,0 & & \\
\hline Sina Weibo & & & & & & & & & 8,1 & 5,4 & & \\
\hline Renren & & & & & & & & & & 0,4 & & \\
\hline
\end{tabular}

Source: Own results

The obtained data show a considerable regional differentiation of social networks regarding active users' coverage. On the whole, we can indicate a growing share of Facebook and the dynamic development of niche and national social media.

The social media markets of Russia and China are competitive and nationally specific. The nationally specific character of the markets is expressed through a relatively high share of social networks created in these countries and spread within their national economies. To a great extent social networks development within national economies is driven by social networking opportunities as well as economic accessibility of social media, competitive environment formation and the preferences of the population. 
The analysis of the data, represented in the global digital market report Global Digital 2018 by We Are Social and Hootsuite, verified the market development volatility of social networks. The trend noted above is driven by mobile phones and internet availability, and, therefore, social networks audience extends through the involvement of young people.

Another trend of social networks development is an increase in the number of field-specific websites of social networks along with universalization of existing platforms: microblogs, instant messengers, communities, and e-commerce as a separate area. With relatively stable profit digital media converge, the cost of calculations and distribution on the Internet rises, therefore companies have to diversify strategies, that is to include a micropayments service, new advertising models, innovative distribution methods, social and web-media content of high quality.

The greatest number of social media sites among popular Internet-resources is depicted in Germany and South Africa; of communication platforms (messengers and e-mails) - in the USA, Germany and South Africa; of games, music and video websites - in Japan and Brazil; news, magazines, and shopping sites - in Japan. The heterogeneity of the needs structure provides diverse conditions for social media development in different regions of the world, leading such global companies like Facebook, Pinterest, Instagram, Twitter, YouTube, LinkedIn, Google + to the necessity of establishing regional development strategies and forming a regional competitive market structure instead of a globally-monopolistic one.

\section{Conclusions}

Entrepreneurship ecosystems formation based on social networks in the context of digitalization is one of the major conditions for making a company's competitive development strategy. Being a driver of the ecosystem development, social networks cause a number of various effects. The economic effects of social networks operating are diverse and not always obvious. The intra-company effects have been most studied because they have a significant impact on financial performance of the company, including marketing, internal operating costs and others. While in the process of developing entrepreneurship ecosystems strategy based on social networks, we should take into account both positive and negative effects.

Thus, at the mini-economic level using social media reduces a company's operating costs, on the one hand, but, on the other hand, demands extra financial and human resources to create an intra-company corporate network. At the microeconomic level using social media expands markets for products though causing an increase in competition among companies. Networking at the meso-economic level is a positive effect; however, there is a shift in industry proportions in the economy towards the services sector. And, finally, at the macroeconomic level using social media encourages the development of the domestic market, but this is accompanied by an increase in costs of control and maintenance of economic institutions.

In addition, the strategy for the development of entrepreneurship ecosystems is to consider regional and content differentiations of social networks. A regional differentiation of social networks is revealed through global markets development of such giant companies like Facebook, Instagram, YouTube and local national markets represented by VKontakte, Youku social networks and others. Russia and China show great interest in social networks and develop national social networks and Internet resources intensively. A content differentiation, caused by field-specific sites development, is a significant trend of social networks development. All these trends define the formation of new entrepreneurship ecosystems based on social networks.

\section{Acknowledgment}

This paper was funded by RFBR according to the research project No. 18-00-00665.

\section{References}

Abrhám J, Wang J (2017) Novel trends on using ICTS in the modern tourism industry. Czech Journal of Social Sciences, Business and Economics 6(1):37-43. doi: 10.24984/cjssbe.2017.6.1.5

Chiabai A, Platt S, Strielkowski W (2014) Eliciting users' preferences for cultural heritage and tourism-related eservices: a tale of three European cities. Tourism Economics 20(2):263-277. doi: 10.5367/te.2013.0290

Drury G (2008) Opinion piece: Social media: Should marketers engage and how can it be done effectively. Journal of Direct, Data and Digital Marketing Practice 9(3):274-277. doi: 10.1057/palgrave.dddmp.4350096 
Grilli L, Mrkajic B, Latifi G (2018) Venture capital in Europe: social capital, formal institutions and mediation effects. Small Business Economics 51:393-410. doi: 10.1007/s11187-018-0007-7

Hornuf L, Schwienbacher A (2018) Internet-based entrepreneurial finance: Lessons from Germany. California Management Review 60(2):150-175. doi: 10.1177/0008125617741126

Lak B, Rezaeenour J (2018) Maturity Assessment of Social Customer Knowledge Management (SCKM) Using Fuzzy Expert System. Journal of Business Economics and Management 19(1):192-212. doi: $10.3846 / 16111699.2018 .1427620$

Lechman E (2018) Networks Externalities as Social Phenomenon in the Process ICT Diffusion. Economics and Sociology 11(1):22-43. doi:10.14254/2071-789X.2018/11-1/2

Martins NO (2016) Ecosystems, strong sustainability and the classical circular economy. Ecological Economics 129:32-39. doi: 10.1016/j.ecolecon.2016.06.003

Obst C, Hein L, Edens B (2016) National accounting and the valuation of ecosystem assets and their services. Environmental and Resource Economics 64(1):1-23. doi: 10.1007/s10640-015-9921-1

Ooms W, Werker C, Caniëls M (2018) Personal and social proximity empowering collaborations: the glue of knowledge networks. Industry and Innovation, 25(9):833-840. doi: 10.1080/13662716.2018.149398

Polzin F, Toxopeus H, Stam E (2018) The wisdom of the crowd in funding: information heterogeneity and social networks of crowdfunders. Small Business Economics 50:251-273. doi: 10.1007/s11187-016-9829-3

Selyanskaya G, Finogenova Y, Strielkowski W (2018) Factor Analysis of Economic Leadership Peculiarities of Countries and Regions Around the World. In: Strielkowski W., Chigisheva O. (eds) Leadership for the Future Sustainable Development of Business and Education. Springer Proceedings in Business and Economics. Springer, Cham, pp. 213-222. doi: 10.1007/978-3-319-74216-8_22

Vermeulen B, Pyka A (2018) The Role of Network Topology and the Spatial Distribution and Structure of Knowledge in Regional Innovation Policy: A Calibrated Agent-Based Model Study. Computer Economics 52:773-808. doi: 10.1007/s10614-017-9776-3.

Wu J, Sun H, Tan Y (2013) Social media research: a review. Journal of Systems Science and Systems Engineering 22(3):257-282. doi: 10.1007/s11518-013-5225-6

Zeng D, Chen H, Lusch R, Li S-H (2010) Social Media Analytics and Intelligence. IEEE Intelligent Systems 25(6):13-16. doi: 10.1109/MIS.2010.151 